Workshops to postdocs and publishing

IN contrast with EMBL, it is hard to find anything but praise for its original parent, the European Molecular Biology Organization (EMBO), which distributes fellowships, finances workshops and practical courses and now produces the EMBO Journal.

EMBO celebrates its silver jubilee this year. Its first grant was a small one from Israel, which to this day qualifies as a European state both for EMBO and EMBL. That was followed by a substantial grant from the Volkswagen Foundation. Finally, in 1969, an intergovernmental agreement established the European Molecular Biology Conference, the body through which EMBO's (but not EMBL's) funds are still provided. With Portugal soon to join and Belgium contributing unofficially, EMBO has a full house, and an annual budget of nearly $£ 4$ million.

The membership is drawn, somewhat unselectively, from the ranks of European molecular biologists. But the keys to its success are the select committees and reviewers, who decide which applications to support, and John Tooze, EMBO's executive secretary. Tooze also manages to edit EMBO Journal, act as scientific coordinator for EMBL and carry out research (four papers in J. Cell Biol. in 1987).

The greatest pressure on EMBO's budget is for long-term fellowships supporting postdoctoral fellows for $1-2$ years in a country other than their own. Demand for these fellowships has increased greatly in the past five years, but plans to meet it were somewhat thwarted by British penny-saving in 1986, when EMBO's existence was guaranteed until 1995 and its budget set until 1991.

As a result, only about 30 per cent of the new applications for long-term fellowships could be financed last year, while about 40 per cent deserved support, says Tooze. Nevertheless, 142 new awards were made, together with 69 renewals of one-year awards for a second year.

Awards, Tooze emphasizes, are made strictly according to the quality of the application. There is no attempt to distribute some of the awards to each of the countries contributing to EMBO's budget - last year, 40 per cent of the new longterm EMBO fellows were working in US laboratories.

Of the original plans for EMBO, only the idea that it should award research grants remains unfulfilled. There are those who believe the time is right to start pressing for EMBO to be allowed to build on its success in that way.

P.N.

\title{
Portrait of a European
}

\section{Parls}

Hubert Curien is a European enthusiast. Perhaps more than anyone, this modest 65-year-old French physicist, who is also research minister in the Socialist French government, has accompanied European science and technology in its trajectory from a collection of national initiatives towards true collaboration.

The European Science Foundation (ESF) and the European Space Agency (ESA), along with the European Commission's EUREKA and PACE programmes, CODEST and, most recently the Academia Europaea, have each benefited from his innovative flair and enthusiasm.

Although he has been president of both ESA and ESF, Curien was first of all an

\section{IMAGE UNAVAILABLE FOR COPYRIGHT REASONS}

Curien - urbane, optimistic and idealistic.

ambassador for French science through his research on crystals and even has a new mineral, 'curienite', named after him. He has been director of the French national science research centre (CNRS) and president of the French national space research centre (CNES). He became Minister for Research and Technology in the 1984 Fabius government until the 1986 elections brought the opposition conservative party to power. In June last year, he once again became Minister for Research and Technology in the new Rocard administration.

Looking back on the past 30 years, Curien acknowledges that personal contacts between scientists inspired the creation of the first European organizations. "European countries did not know each other well in the $1960 \mathrm{~s}$ ", he says. So it was as a result of informal contacts between colleagues such as Curien, Lord Flowers and Reimar Lüst that the European Science Foundation and ESA got off the ground. "Now", he says, "we know each other better" and there is a European synergy arising from the various organizations and forums that have been established.

Historically it was through the creation of joint large scientific instruments, such as CERN, that European scientists found they could buy their own cake and eat it, without having to be guests at the table of US colleagues. Other examples have followed, including the European Southern Observatory and the European Synchrotron Radiation Facility. But for Curien, European collaboration in science and technology means more than sharing expensive facilities. It is also a matter of bringing scientists together, not only to exchange ideas, but to influence policy.

"If thinking comes from the bottom and the money from the top, people at the bottom find themselves in a very happy situation, and as it is the people at the bottom who do the work, it is better if they are heard", Curien said in his keynote address at the foundation of the European Academy last year. And this 'bottom up' approach is the hallmark of initiatives in which he has played a central role.

EUREKA, Curien's brainchild, provides for trans-frontier technology collaboration where the projects are marketled. Similarly, CODEST, the European Commission's (EC) Committee for European Development of Science and Technology, is a platform for specialists to influence policy, while the proposed EC Assembly, due to be debated this year, will give 200 academics a voice in Brussels.

Perhaps because his own roots are still in the laboratory, Curien knows that the whole is also composed of parts which can easily find themselves isolated. It was he who first proposed the idea of 'networks' of laboratories as an alternative to the 'lame-duck' idea of European centres of excellence. Since 1974, 20 networks have been set up in specific disciplines, largely through ESF.

Now, as Europe finds its stride, Curien sees a danger that countries such as Greece and Portugal will find it difficult to keep up. "European cohesion can easily be opposed to excellence", he says. In areas at the vanguard of science and technology, he says, poorer countries may lack the facilities or trained researchers to take part. But if Europe opts for cohesion and drops these projects, the best are brought down to the level of the least good. For Curien, one way to achieve cohesion and excellence is through education.

The EuroPACE satellite teaching programme for continuing education, of which he is president, is one means to achieve equality of skills. He also wants to see more part-time posts in universities to allow researchers from poorer countries to keep a foot in good laboratories while raising standards at home.

Urbane, optimistic and idealistic, Curien continues to seek ways in which European collaboration can improve. "We cannot imagine Europe continuing as it is now. It must be more coherent." But, he adds, "with patience you can always get what you want".

P.C. 